\title{
Use of Bioluminescence for Monitoring Brown Coal Mine Waters from Deep and Surface Drainage
}

\author{
Ryszard Staniszewski $^{1} \mathbb{D}$, Dorota Cais-Sokolińska ${ }^{2, *} \mathbb{D}$, Lukasz K. Kaczyński $^{2} \mathbb{D}$ and Paulina Bielska ${ }^{2} \mathbb{D}$ \\ 1 Department of Ecology and Environmental Protection, Faculty of Environmental and Mechanical \\ Engineering, University of Life Sciences, 94C Piątkowska Street, 60-649 Poznań, Poland; \\ ryszard.staniszewski@up.poznan.pl \\ 2 Department of Dairy Products Quality, Faculty of Food Science and Nutrition, Poznań University of Life \\ Sciences, 31 Wojska Polskiego Street, 60-624 Poznań, Poland; lukasz.kaczynski@up.poznan.pl (Ł.K.K.); \\ paulina.bielska@up.poznan.pl (P.B.) \\ * Correspondence: cais@up.poznan.pl; Tel.: +48-61-848-7317
}

Citation: Staniszewski, R.;

Cais-Sokolińska, D.; Kaczyński, Ł.K.; Bielska, P. Use of Bioluminescence for Monitoring Brown Coal Mine Waters from Deep and Surface Drainage. Energies 2021, 14, 3558. https:// doi.org/10.3390/en14123558

Academic Editor: Ben McLellan

Received: 10 May 2021

Accepted: 13 June 2021

Published: 15 June 2021

Publisher's Note: MDPI stays neutral with regard to jurisdictional claims in published maps and institutional affiliations.

Copyright: (c) 2021 by the authors. Licensee MDPI, Basel, Switzerland. This article is an open access article distributed under the terms and conditions of the Creative Commons Attribution (CC BY) license (https:// creativecommons.org/licenses/by/ $4.0 /)$.

\begin{abstract}
Open-pit mines can cause environmental changes, such as alterations of landscape structure, hydrology, air quality, and river sediments; they can also generate cones of depression. We propose a new method for surveys of mine waters using the example of an open-pit mine in central Poland. This study examines the correlations between bioluminescence and the color of brown coal mine waters and tests whether values of the three-color coordinate system reflected the physicochemical quality of mine waters measured in real-time and in the field. Our results show that alkalinity, $\mathrm{pH}$ reaction, and conductivity are higher in surface drainage, while values of trophic parameters (soluble reactive phosphates, total phosphorus, nitrates) are greater in samples representing subsurface drainage. Correlation analysis of bioluminescence with mine water quality parameters showed that only water color had a strong association with bioluminescence. This correlation is stronger for surface drainage, than for mine waters from subsurface drainage. Direct measurement of bioluminescence, resulting from adenosine 5 'triphosphate (ATP) using a luminometer, is a fast and reliable method for evaluation of the characteristics of mine waters in real-time.
\end{abstract}

Keywords: brown coal; mine waters; color; water activity; bioluminescence

\section{Introduction}

Brown coal is an important natural resource for electric power generation in several countries, e.g., Germany, Turkey, China, Poland, Russian Federation, Greece, and others. The top brown coal producers in the European Union are Germany, followed by Poland [1]. In all those countries, the impact on aquatic and terrestrial ecosystems can be observed near operating and closed open-pit mines. Amongst several environmental effects of open-cast mines in the presence of cone of depression in the surrounding area, which affect not only groundwater table, but also the availability of surface waters, due to drying out of small lakes, ponds, and even watercourses. This phenomenon is an unavoidable consequence of the drainage of brown coal deposits [2,3]. This complicates the hydrological situation, especially in areas with frequent hydrological droughts. Open-mines activity can limit the agricultural usefulness of organic soils, due to changes in moisture and subsequently the physicochemical properties [4]. The quality of mine waters differs according to the type of drainage. In general, waters from deep-seated drainage had good quality in terms of transparency, salinity, and presence of heavy metals. Another type, from surface drainage, had poorer quality, and it was related to the presence of ions and especially to turbidity [5].

Environmental problems related to the lignite open-pit mines have been surveyed by only a limited number of authors and studies, mostly concerning impacts on groundwaters, mine waters volume, impact on agriculture, landscape changes, air quality modifications, and treatment processes, but omitting mine waters impact on river ecosystem [3,6-9]. 
Physicochemical parameters of brown coal mine waters differ between regions, i.e., mine waters can have variable concentrations of trace elements, total phosphorus, or conductivity [5]. In some areas, reactions causing low $\mathrm{pH}$ in the mine waters are linked to the problem of acid mine drainage (AMD), an additional environmental impact of mining [10]. In general, two types of brown coal mine waters can be distinguished: Surface mine waters and deep-seated drainage. The most visible differences between them are transparency (much higher in deep drainage), turbidity (higher in surface drainage), temperature, and oxygen concentrations (deep drainage waters tend to be deoxygenated).

Deep drainage mine waters are normally clean enough to be discharged directly to rivers, and sometimes its quality is good as in drinking waters. Mine waters from surface drainage require treatment in settling ponds to reduce turbidity and to improve physicochemical quality, e.g., reduction of concentrations of phosphorus or selected metals.

In this study, we investigated the (possibly innovative) method for evaluating overall metabolic activity in mine water by measuring the amount of adenosine $5^{\prime}$-triphosphate (ATP) using bioluminescence. The method was very fast, relatively cheap, and easy to use even under field conditions. This method allows researchers to determine the whole pool of ATP present in bacteria, protozoa, and fungi cells. Bioluminescence is a widespread phenomenon in nature and involves the production of light by living organisms [11]. Light is related to the enzymatic oxidation of luciferin catalyzed by luciferase [12]. The reaction requires ATP and ions of magnesium. ATP is present in every living cell (bacteria, fungi, and protozoa) and material of biological origin. It acts as an energy carrier and participates in the metabolic processes of cells. Dead cells do not contain ATP. ATP is then hydrolyzed to adenosine-5'-diphosphate (ADP) or adenosine-5'-monophosphate (AMP). Oxidation produces an activated OxyLH2 (oxyluciferin) molecule. The return from the activation state to a lower energy state is associated with releasing large amounts of free energy, which can be measured as emissions of light quanta. Hammes et al. [11] studied the viability of natural microbial communities in aquatic environments, such as drinking water, groundwater, bottled water, river water, lake water, and wastewaters. They found that the average ATP concentration was $1.75 \times 10^{-10} \mathrm{nmol} /$ cell. The authors have experience in using ATP analyses to assess the state of surface cleanliness of abiogenic materials used in the food industry $[13,14]$. One component of the research was to examine correlations between bioluminescence and the color of brown coal mine waters, and to test whether values of the three-color coordinate system reflected the physicochemical quality of mine waters. Another question investigated was whether biochemical parameters that differentiated mine waters from other waters influenced chroma.

We hypothesized a relationship exists between the metabolic activity in surface and deep mine water drainage and the color of the water measured in real-time and in the field. Outcomes of this study can be the first steps toward establishing a new and fast microbiological method helpful in mine water quality assessment. Traditional methods of enumerating microorganisms are laborious, and above all, time-consuming [15], averaging $72 \mathrm{~h}$, and in some cases up to 7 days [16]. The significance of studies to evaluate minewater effects on the river ecosystem was also related to the need to precisely identify full mixing zone length. Knowing this length is important because of the possible need to shorten this path [17], for example, by changing of river width or introducing deflectors. This understanding is particularly important in an era of moving away from coal as a power resource and trying to reduce the environmental impact of mining and coal power generation, which will be slowly phased out through 2040 [18].

\section{Materials and Methods}

\subsection{The Sampling of the Brown Coal Mine Waters}

Mine waters were sampled from two channels at the Tomisławice open-pit mine, located in central Poland (latitude $52^{\circ} 29^{\prime} 8^{\prime \prime} \mathrm{N}$, longitude $18^{\circ} 30^{\prime} 9^{\prime \prime} \mathrm{E}$ ).

All mine water samples were collected in $0.5 \mathrm{~L}$ polyethylene bottles and transported to the laboratory on ice, within $6 \mathrm{~h}$. Surface samples of mine waters were collected in the 
middle of the channels. To maintain sampling precision, the sampler faced upstream, and each water sample was collected without disturbing channel sediments. Special attention was paid to avoid contaminating PVC samplers during storage, and they were rinsed with the waters to be sampled before final sampling and transport on ice.

Tomisławice open-pit mine waters were sampled $(n=11)$ in April and June 2019. It was a vegetation season of the year suitable for studies of the freshwater ecosystem in the case of biological aspects. Waters were sampled at two sites. Site A was situated on an artificial concrete channel where mine waters from deep drainage were discharged. Site B was located in the channel of the Pichna River (actually dry near a pit mine), where surface drainage was released (after treatment in a settling pond and mixing with waters from deep-seated drainage in about 10 to 1 proportion).

\subsection{Physicochemical Analyses}

The following chemical analyses of mine waters were performed using a $\mathrm{HACH}$ spectrophotometer DR2700 using surface samples collected during field studies [19-21]. Soluble reactive phosphorus (SRP): Samples were filtered through $0.45 \mu \mathrm{m}$ pore size Whatman membranes and analyzed by the ascorbic acid method. Nitrates: Samples were filtered as for SRP and analyzed by the cadmium reduction method. Total phosphorus (TP) was analyzed by the acid persulfate digestion method, without filtration.

Conductivity and $\mathrm{pH}$ were measured in the field. The apparent and true color of mine waters were analyzed using laboratory test methods: Apparent color by the HACH APHA Platinum-Cobalt standard, and true color by the same standard after filtration.

\subsection{Water Activity}

Water activity, an indicator of the potential for microbial development, was analyzed with an AquaLab Series 4TE instrument (Decagon Devices Inc., Pullman, WA, USA) equipped with a thermostatic chamber controlled using measuring elements using the thermoelectric Peltier effect. Higher values of aw indicate more potential for microbial development in the sampled water. Water activity $\left(a_{\mathrm{w}}\right)$ is the ratio of the vapor pressure of water in a material $\mathrm{p}(\mathrm{Pa})$ to the vapor pressure of pure water $\mathrm{p}_{\mathrm{o}}(\mathrm{Pa})$ at the same temperature [22]. The accuracy of the measurement was $\pm 0.003 a_{\mathrm{w}}(\mathrm{Pa} / \mathrm{Pa})$ and the measuring range $0.03-1.000 a_{\mathrm{w}}$. The following salt solutions were used for reference: $0.5 \mathrm{M} \mathrm{KCl}$ $\left(a_{\mathrm{w}}=0.984 \mathrm{~Pa} / \mathrm{Pa}\right.$ at $\left.15^{\circ} \mathrm{C}\right), 6 \mathrm{M} \mathrm{NaCl}\left(a_{\mathrm{w}}=0.760 \mathrm{~Pa} / \mathrm{Pa}\right.$ at $\left.20^{\circ} \mathrm{C}\right), 8.57 \mathrm{M} \mathrm{LiCl}\left(a_{\mathrm{w}}=0.500\right.$ $\mathrm{Pa} / \mathrm{Pa}$ at $\left.25^{\circ} \mathrm{C}\right)$ and $13.41 \mathrm{M} \mathrm{LiCl}\left(a_{\mathrm{w}}=0.250 \mathrm{~Pa} / \mathrm{Pa}\right.$ at $\left.25^{\circ} \mathrm{C}\right)$. Samples of volume $=15 \mathrm{~mL}$ were placed in a DE 501 measurement vessel (Decagon Devices Inc., Pullman, WA, USA) and tested at $15^{\circ} \mathrm{C}$.

\subsection{Freezing Point}

The freezing point of the water was determined according to the ISO 5764 [23] (In ISO 5764 (2009). Milk-Determination of freezing point-Thermistor cryoscope method Reference Method. IDF bulletin $\mathrm{N}^{\circ}$ 42. Brussels, Belgium: International Dairy Federation. WAITDELETE) standard method using an Advanced ${ }^{\circledR}$ Model 4D3 cryoscope with a 3LH700 thermistor probe (Advanced Instruments Inc., Norwood, MA, USA). The calibration process was carried out using calibration standards $-0.422^{\circ} \mathrm{H}\left(-0.408^{\circ} \mathrm{C}\right),-0.621^{\circ} \mathrm{H}$ $\left(-0.600{ }^{\circ} \mathrm{C}\right)$, and Lactrol 530 reference solution $-0.530{ }^{\circ} \mathrm{H}\left(-0.512{ }^{\circ} \mathrm{C}\right)$ for use with Advanced Instruments cryoscopes. The water was poured into $2 \mathrm{~mL}$ sample tubes (DZ 3LA823, Advanced Instruments Inc., Norwood, MA, USA).

\subsection{Bioluminescence}

Bioluminescence in mine water samples of $0.15 \mathrm{~mL}$ was based on ATP analyses with a luminometer (FireFly Charm Sciences Inc., Malden, MA, USA) and swabs (PocketSwab Plus Charm Science Inc., Lawrence, KS, USA). Measurements were performed following the instructions of the manufacturers of the meter and swabs, and recorded in relative light units (RLU). The temperature of the samples during the measurement was $6-10{ }^{\circ} \mathrm{C}$. 


\subsection{Color}

Color measurements were based on the CIELAB color space. A water sample was placed in an optical glass cuvette 2/96G/10 (Starna Scientific Company Ltd., Ilford, UK). The measurement was performed with a D65 light source, and a $10^{\circ}$ observation angle, with geometry SPIN, using an X-Rite SP-60 camera (Grandville, MI, USA) equipped with spherical geometry (diffusive), and a measurement chamber with a DRS-811 ceramic insert. The camera was calibrated based on the white and black reference standards SP-62-162 (Grandville, MI, USA). The chroma $\left(C^{*}\right)$ was calculated using Equation (1) and whiteness index (WI) using Equation (2). The calculations assumed that ideal white is defined by $\mathrm{L}^{*}=100, \mathrm{a}^{*}=0$, and $\mathrm{b}^{*}=0$.

$$
\begin{gathered}
\mathrm{C}^{*}=\left[\left(\Delta \mathrm{a}^{*}\right)^{2}+\left(\Delta \mathrm{b}^{*}\right)^{2}\right]^{0.5} \\
\mathrm{WI}=\left[\left(\Delta \mathrm{L}^{*}\right)^{2}+\left(\Delta \mathrm{a}^{*}\right)^{2}+\left(\Delta \mathrm{b}^{*}\right)^{2}\right]^{0.5}
\end{gathered}
$$

\subsection{Statistical Evaluation}

For tests of statistical hypotheses, a level of significance of $p=0.05$ was adopted. A one way analysis of variance was conducted to test properties of water from the surface versus deep mine drainage for thirteen items (traits) within physicochemical characteristics and color parameters. The statistical calculations were carried out using Statistica data analysis software, version 13 (TIBCO Software Inc., Palo Alto, CA, USA).

\section{Results}

\subsection{Basic Chemical Composition and Selected Quality Characteristics}

The type of mine water affected nitrate concentrations and alkalinity $(p>0.05$, Table 1$)$. Differences also were observed in $\mathrm{pH}$ and conductivity. Water activity from deep drainage (sample A; $\left.a_{\mathrm{w}}=0.974 \mathrm{~Pa} / \mathrm{Pa}\right)$ was similar to aw in surface drainage $(0.971 \mathrm{~Pa} / \mathrm{Pa}$, Figure 1$)$. No effect of mine water type on freezing point was found ( $p>0.05$, Figure 1$)$. The mean freezing point of deep mine waters was $-0.015^{\circ} \mathrm{C}$, and from surface drainage $-0.019{ }^{\circ} \mathrm{C}$. Freezing points ranged between -0.022 and $-0.011^{\circ} \mathrm{C}$.

\begin{tabular}{|c|c|c|c|c|c|}
\hline \multirow{3}{*}{ Parameter } & \multicolumn{4}{|c|}{ Mine Waters } & \multirow{3}{*}{ MSE } \\
\hline & \multicolumn{2}{|r|}{$\mathbf{A}$} & \multicolumn{2}{|r|}{ B } & \\
\hline & Mean & $\mathbf{P}_{5}-\mathbf{P}_{95}$ & Mean & $\mathbf{P}_{5}-\mathbf{P}_{95}$ & \\
\hline $\begin{array}{c}\text { Nitrates (mg } \\
\left.\mathrm{N}-\mathrm{NO}_{3} / \mathrm{L}\right)\end{array}$ & $0.09 \mathrm{~b}$ & $0.07-0.09$ & $0.01 \mathrm{a}$ & $0.01-0.02$ & 0.000 \\
\hline $\mathrm{SRP}(\mathrm{mg} \mathrm{PO} / \mathrm{L})$ & 0.35 & $0.30-0.39$ & 0.30 & $0.09-0.51$ & 0.012 \\
\hline $\mathrm{TP}(\mathrm{mg} \mathrm{P} / \mathrm{L})$ & 0.26 & $0.23-0.29$ & 0.22 & $0.12-0.33$ & 0.004 \\
\hline $\begin{array}{c}\text { Alkalinity (mg } \\
\left.\mathrm{CaCO}_{3} / \mathrm{L}\right)\end{array}$ & $304.46 \mathrm{a}$ & $290.02-318.88$ & $347.80 \mathrm{~b}$ & $336.20-359.39$ & 354.540 \\
\hline $\mathrm{pH}$ reaction $(-)$ * & $7.96 \mathrm{a}$ & $7.89-8.05$ & $8.13 \mathrm{~b}$ & $7.86-8.54$ & 0.032 \\
\hline $\begin{array}{l}\text { Conductivity } \\
(\mathrm{mS} / \mathrm{cm})\end{array}$ & $0.60 \mathrm{a}$ & $0.58-0.63$ & $0.69 \mathrm{~b}$ & $0.67-0.72$ & 0.001 \\
\hline
\end{tabular}

Table 1. Physicochemical characteristics of studied brown coal mine waters.

A, mine waters from deep-seated drainage; $\mathrm{B}$, mine waters from surface drainage; SRP, soluble reactive phosphates TP, total phosphorus; $\mathrm{P}_{5}-\mathrm{P}_{95}$, confidence interval of the mean; MSE, mean square error of inter-group (A and B) variability. Different small letters in superscript in the rows indicate statistically significant differences at the level $p=0.05 .{ }^{*}$ mean $\mathrm{pH}$ calculated using a mean concentration of $\mathrm{H}^{+}$. 


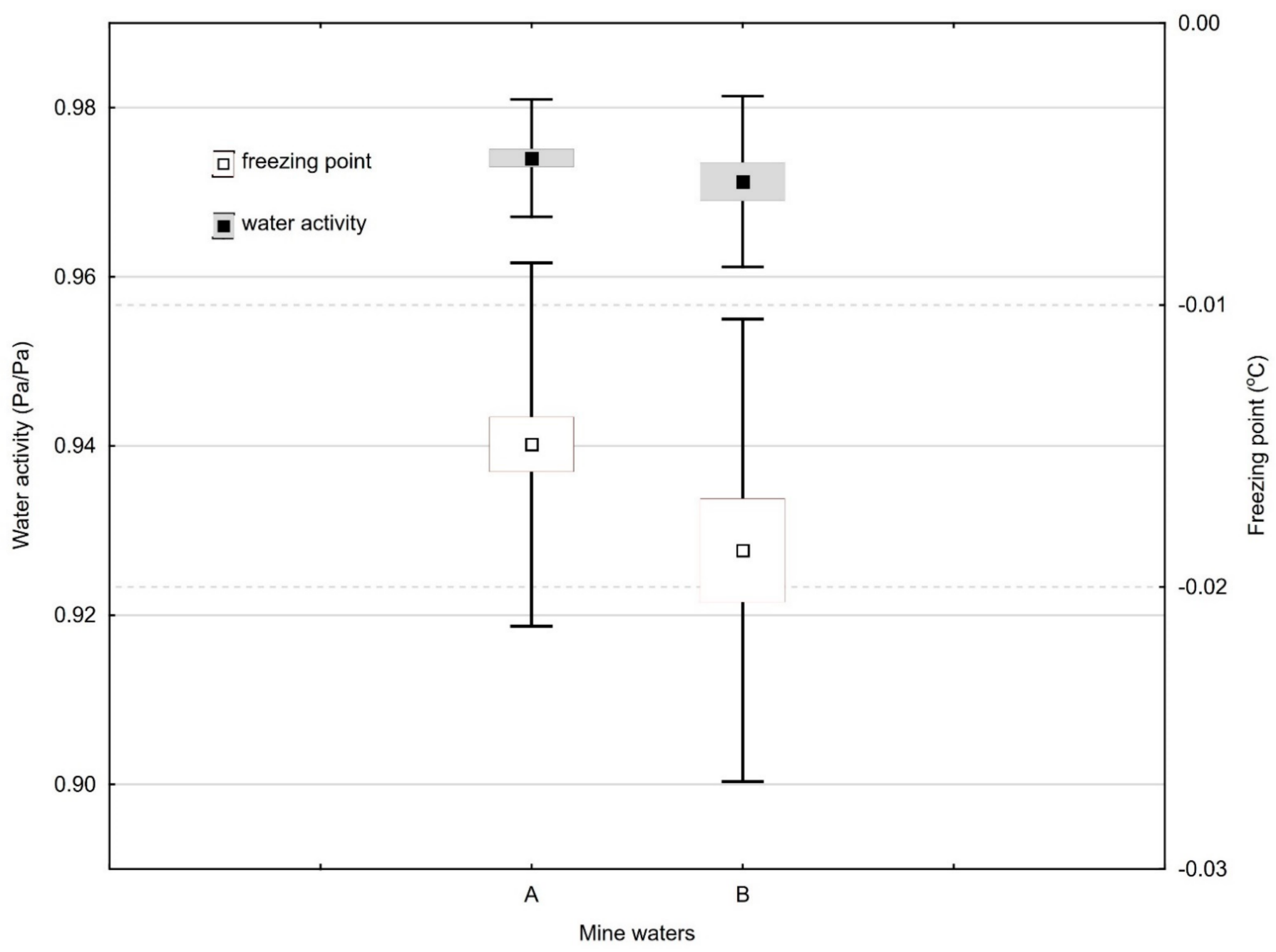

Figure 1. Water activity and freezing point of mine waters (mean $\pm \mathrm{SD} ; \mathrm{P}_{5}-\mathrm{P}_{95}$ ). A, mine waters from deep-seated drainage; $\mathrm{B}$, mine waters from surface drainage; SD, standard deviation.

Surface drainage waters were turbid and had higher values of parameters, such as like $\mathrm{pH}$ reaction, conductivity, and alkalinity (Table 1). On the contrary, surface drainage had lower mean values of trophic parameters in comparison to deep-seated drainage, including nitrates (mean value equal to $0.09 \mathrm{mg} \mathrm{N}-\mathrm{NO} 3 / \mathrm{L}$ ), soluble reactive phosphates (mean $0.35 \mathrm{mg} \mathrm{PO} 4 / \mathrm{L}$ ), and total phosphorus (mean $0.26 \mathrm{mg} \mathrm{P} / \mathrm{L}$ ). In waters from deepseated drainage, the $\mathrm{pH}$ reaction ranged from 7.8 to 8.2 and conductivity from 0.536 to $0.624 \mathrm{mS} / \mathrm{cm}$, while in the case of surface drainage, the range of $\mathrm{pH}$ was from 7.9 to 8.4, and conductivity was also higher and varied from 0.676 to $0.710 \mathrm{mS} / \mathrm{cm}$. Surveyed water quality parameters were far below thresholds established by the Regulation of the Minister of Maritime Economy and Inland Navigation [24] for maximum permissible values for other pollutants that those particularly harmful to the aquatic environment.

Mine waters from surface drainage are normally very turbid and could not be discharged directly to rivers. They were treated in settling ponds, and iron coagulant was added to improve the rate of purification. Iron coagulants are widely used to remove phosphorus compounds and, to some extent, hydrogen sulfide. It could explain the low concentration of SRP and TP in this kind of mine waters. Even after treatment, surface mine waters are characterized by high values of conductivity, due to solids remaining in waters despite the treatment. Mine waters from deep-seated drainage have lower conductivity and also lower $\mathrm{pH}$. Low conductivity is predominant in such waters, and because of predominantly good chemical quality, they can be used as drinking water. Mine waters from deep-seated drainage have a lower $\mathrm{pH}$ reaction, due to $\mathrm{CO}_{2}$ and limited concentration of 
dissolved oxygen (tertiary and quaternary waters). Higher concentrations of phosphorus could be explained by the geological characteristics of open-pit mines; this phenomenon was also observed in nearby pit mines.

Experimental results by Ming et al. [25] show that the freezing point is related to the energy status of liquid water in saline soils. The freezing point becomes lower the greater the salt concentration. The freezing point depression of saline soil is mainly caused by the decrease in water activity. This measurement of the freezing point is relevant for, e.g., engineering construction in saline soil areas. There is a dependency of the freezing points on the contents in mineral salts. According to Martuzzi et al. [26], the freezing point in raw materials of animal origin decreases when mineral salts are increased. Furthermore, the freezing point also depends on the biochemical composition of the soluble phase; thus, 55\% of the total variability was associated with lactose, $25 \%$ with salts, especially $\mathrm{Cl}^{-}$, and the remaining $20 \%$ by $\mathrm{Ca}_{2}{ }^{+}, \mathrm{K}^{+}, \mathrm{Mg}^{2+}$, lactate, citrate, and phosphate. The presence of such solutes causes depression of the freezing point below zero degrees $C$ [27].

\subsection{Color Parameters, Color and Whiteness Indices}

In the case of mine waters from deep-seated drainage, both apparent and true color of water was similar to drinking water with values below $10 \mathrm{Pt} / \mathrm{Co}$ (Table 2). Turbidity of surface drainage was proved by apparent water color with a maximum value equal to $62 \mathrm{Pt} / \mathrm{Co}$ and a mean value equal to $39 \mathrm{Pt} / \mathrm{Co}$.

Table 2. Assessment of the color of mine waters.

\begin{tabular}{|c|c|c|c|c|c|}
\hline \multirow{3}{*}{ Item } & \multicolumn{4}{|c|}{ Mine Waters } & \multirow{3}{*}{ MSE } \\
\hline & \multicolumn{2}{|c|}{ A } & \multicolumn{2}{|c|}{ B } & \\
\hline & Mean & $\mathbf{P}_{5}-\mathbf{P}_{95}$ & Mean & $\mathbf{P}_{5}-\mathbf{P}_{95}$ & \\
\hline \multicolumn{6}{|c|}{ Platinum-Cobalt Standard } \\
\hline $\begin{array}{l}\text { Apparent } \\
\text { color }\end{array}$ & $7.55 \mathrm{a}$ & $5.63-9.45$ & $39.00 \mathrm{~b}$ & $18.56-59.44$ & 83.20 \\
\hline \multicolumn{6}{|c|}{ Platinum-Cobalt Standard after filtration } \\
\hline True color & $4.27 \mathrm{a}$ & $2.65-5.89$ & $21.80 \mathrm{~b}$ & $20.18-23.42$ & 4.642 \\
\hline \multicolumn{6}{|c|}{ CIELAB color space } \\
\hline$L^{*}(\%)$ & 26.01 & $25.65-26.38$ & 25.31 & $24.09-26.53$ & 0.486 \\
\hline$a^{*}$ & -0.06 & $-0.08--0.05$ & -0.04 & $-0.08-0.00$ & 0.001 \\
\hline$b^{*}$ & $-0.54 \mathrm{a}$ & $-0.68--0.40$ & $-0.03 b$ & $-0.08-0.01$ & 0.029 \\
\hline$C^{*}$ & $0.54 \mathrm{~b}$ & $0.41-0.68$ & $0.06 \mathrm{a}$ & $0.02-0.10$ & 0.029 \\
\hline WI $(\%)$ & 73.99 & $73.62-74.35$ & 74.69 & $73.47-75.91$ & 0.487 \\
\hline
\end{tabular}

A, mine waters from deep-seated drainage; $\mathrm{B}$, mine waters from surface drainage; $\mathrm{L}^{*}$, lightness; $\mathrm{a}^{*}$, -green/+red color; $b^{*}$,-blue/+yellow; $C^{*}$, chroma; WI, whiteness index; $P_{5-} P_{95}$, confidence interval of the mean; MSE, mean square error of inter-group (A and B) variability. Different small letters in superscript in the rows indicate statistically significant differences at the level $p=0.05$.

The whiteness index for deep and surface mine waters (26.01 and $25.31 \%$, respectively) did not differ significantly $(p>0.05$, Table 2$)$. Both types of mine waters were the same distance from the model of perfect white by about $74 \%$. There were also no differences in parameter $\mathrm{a}^{*}$, the -green/+red axis $(-0.06$ and -0.04 , respectively, $p>0.05)$. The -blue/+yellow axis parameter was -0.54 in sample A) and -0.03 in sample B. This difference represented a significant color effect $(p<0.05)$.

\subsection{Bioluminescence and Correlation with Selected Quality Parameters}

Earlier studies showed that biological indicators based on macrophytes, which are good measures of ecological state, were not suited for evaluation of mine waters. Differences were insignificant despite changes in species structure, thus biological diversity indices gave more accurate results [28]. But in this study, the two methods generated different answers. In such circumstances, an additional approach would be useful for 
determining the presence of brown coal mine waters in watercourses. This study has demonstrated that it is possible to use the luminometer directly in analyses of mine water bioluminescence, with almost immediate results. Bioluminescence measured in mine waters from deep drainage (186 RLU, $\mathrm{P}_{5}-\mathrm{P}_{95}$ from 168 to 204) was significantly different $(p<0.05)$ from luminometer results in surface mine waters (141 RLU, $\mathrm{P}_{5}-\mathrm{P}_{95}$ from 137 to 144, Figure 2).

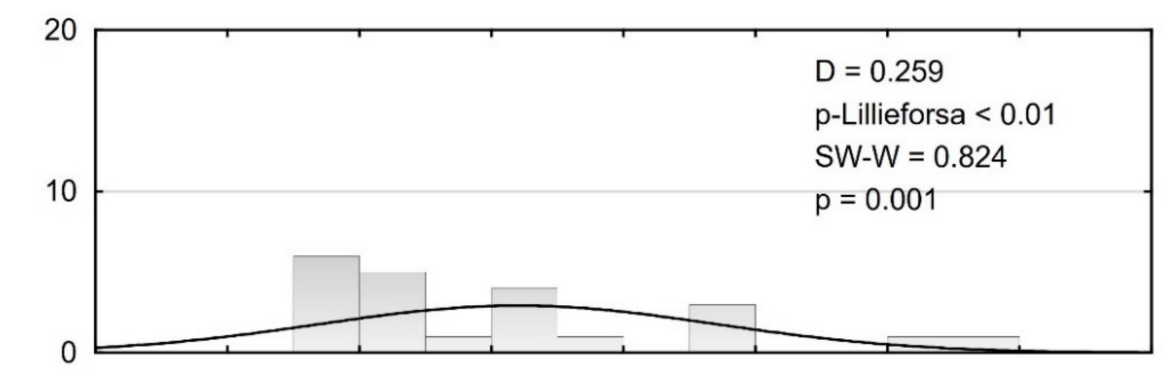

$$
\begin{aligned}
& y=-1.076+0.008 x \\
& r=0.883 \\
& p=0.000
\end{aligned}
$$
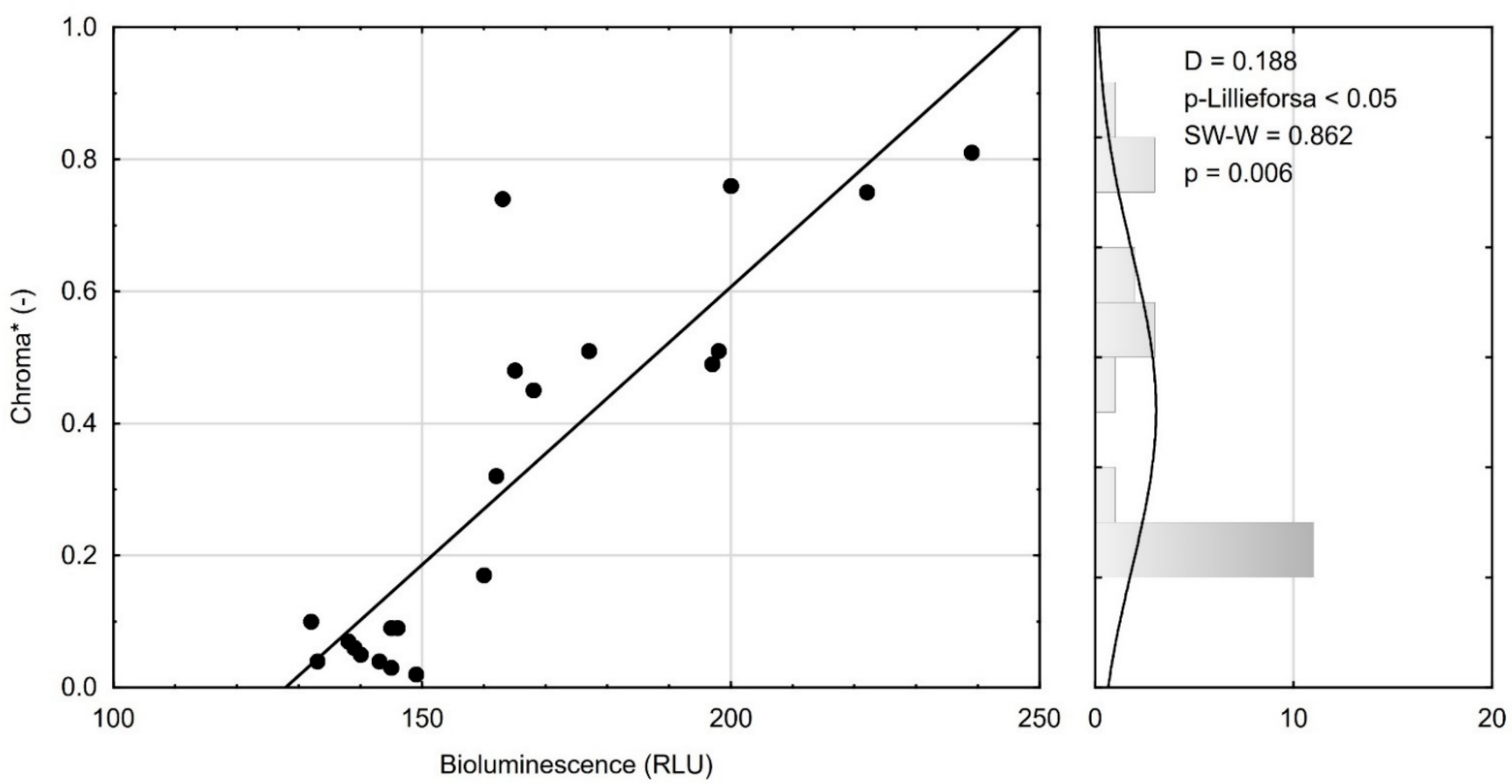

Figure 2. Relative probability of distribution of bioluminescence and chroma of mine waters despite the type of mine waters $(n=22)$. SW-W, Shapiro-Wilk test; D, value of the test statistic Lilliefors test.

Among these modern methods is ATP measurement using a luminometer. Deininger and Lee [19] proved that ATP tests can indicate the microbial quality of drinking water within $5 \mathrm{~min}$. Their results showed that the rapid ATP test is strongly correlated with the conventional plate counting method and the DVC method (direct number of viable bacteria). In recent literature, ATP in water has rarely been reported in RLU units. More often, the data have been converted to ATP concentrations in $\mathrm{pg} / \mathrm{mL}$. The results of ATP measurements of samples of water supplied to dental instruments (air/water syringe, high-speed turbine, micromotor, and cup filler) ranged from 6 to 1189 RLU [29].

In correlation analysis of bioluminescence with other mine water quality parameters (Table 3), only water color had a strong association with bioluminescence $(p<0.05)$. This correlation was stronger for surface drainage $(r=0.879, \mathrm{WD}=77.31)$, than for mine waters from deep drainage $(r=0.697, \mathrm{WD}=48.61)$. Combining the two types of mine water in a joint analysis resulted in a stronger correlation between water color and bioluminescence $(\mathrm{r}=0.883, \mathrm{WD}=77.97)$, demonstrating that the probabilities were additive (Figure 2$)$. 
Table 3. Correlation between bioluminescence ( $x$, RLU) and selected parameters of mine waters.

\begin{tabular}{|c|c|c|c|c|c|c|c|c|}
\hline \multirow{3}{*}{$\begin{array}{c}\text { Quality } \\
\text { Parameter (y) }\end{array}$} & \multicolumn{8}{|c|}{ Mine Waters } \\
\hline & \multicolumn{4}{|c|}{ A } & \multicolumn{4}{|c|}{ B } \\
\hline & WD & $a$ & $b$ & $p$ & WD & $a$ & $b$ & $p$ \\
\hline $\begin{array}{l}\text { Nitrates (mg } \\
\left.\mathrm{N}-\mathrm{NO}_{3} / \mathrm{L}\right)\end{array}$ & 0.57 & $-5.53 \times 10^{5}$ & 0.09 & 0.826 & 0.01 & $-8.43 \times 106$ & 0.02 & 0.985 \\
\hline $\begin{array}{c}\text { Alkalinity (mg } \\
\left.\mathrm{CaCO}_{3} / \mathrm{L}\right)\end{array}$ & 9.24 & -0.24 & 349.86 & 0.363 & 16.38 & -0.49 & 416.80 & 0.499 \\
\hline $\mathrm{pH}$ reaction (-) & 0.92 & -0.01 & 8.05 & 0.779 & 9.50 & 0.01 & 6.66 & 0.614 \\
\hline $\begin{array}{l}\text { Conductivity } \\
(\mathrm{mS} / \mathrm{cm})\end{array}$ & 0.05 & 2.80 & 0.60 & 0.947 & 9.44 & -0.01 & 0.78 & 0.615 \\
\hline Apparent color & 5.41 & 0.03 & 2.95 & 0.491 & 2.25 & -0.32 & 84.05 & 0.810 \\
\hline$C^{*}$ & 48.61 & 0.01 & -0.43 & 0.017 & 77.31 & 0.00 & -0.50 & 0.049 \\
\hline$a_{\mathrm{w}}(\mathrm{Pa} / \mathrm{Pa})$ & 0.02 & 1.85 & 0.97 & 0.967 & 35.88 & 0.00 & 0.92 & 0.268 \\
\hline
\end{tabular}

$\mathrm{A}$, mine waters from deep-seated drainage; $\mathrm{B}$, mine waters from surface drainage; $\mathrm{C}^{*}$, chroma; $a_{\mathrm{W}}$, water activity; $\mathrm{WD}$, linear determination index $(\%) ; a, b$, linear adjustment coefficients $\mathrm{y}=a \mathrm{x}+b$.

Magic-Knezev and Van Der Kooij [30] proved that ATP concentrations correlated significantly with total direct bacterial cell counts in 30 different granular activated carbon filters (GAC) at nine treatment plants in the Netherlands. The ATP concentrations ranged from 25 to $5000 \mathrm{ng}$ ATP $\mathrm{cm}^{-3}$ GAC. The ATP assay was more efficient in the detection of contaminants than total direct counts [31]. Authors have used ATP measurement to detect microbial activity in mine waters from the surface (turbid mixed waters) and deep-seated drainage. Compared to traditional microbiological methods, the ATP assay could detect contamination by mine waters or other effluents of river and drinking waters to a higher degree than total direct counts. Studies by Li et al. [32] showed that ATP luminescence had a strong correlation with bio-growth in reclaimed waters. These authors proposed combining ATP luminescence with assimilable organic carbon, which provides a new approach for monitoring the biological stability of reclaimed waters. Measurement of ATP was an effective method for assessment of active biomass of acidophilic microorganisms in pure cultures and in leach liquors from mineral bio-processing operation [33].

Analyses of bioluminescence were correlated with optical density measurements, as shown by Greenstein and Wert [34] in studies related to monitoring and treating cultured and naturally occurring cyanobacteria cells in surface water. Measurements of ATP correlated $\left(R^{2}=0.791\right)$ with chlorophyll-a concentrations $(\leq 50 \mu \mathrm{g} / \mathrm{L})$. These values were independent of cell morphology artifacts. ATP analysis circumvents interferences, e.g., from turbidity and light scattering particles [35] or from natural organic matter and organic matter released from cells [36]. Bioluminescence was used to rapidly detect microbial contamination in aqueous polymer emulsions by Montanez et al. [15]; the method was easy to execute, with repeatable results. A high coefficient of determination $\left(R^{2}>0.960\right)$ was observed to correlate measured cellular ATP and culturable microbes in aqueous polymer emulsions.

\section{Conclusions}

Differences between studied mine waters were found according to all physicochemical parameters. Mine waters from deep-seated drainage had lower conductivity and $\mathrm{pH}$ reaction, but slightly higher values of trophic parameters. Much more clear variability was observed in the case of ATP analyses.

To our knowledge, this is the first report on the successful use of ATP detection to assess the quality of mine waters. Given the worldwide importance of the mining problem, each possibility for a more scientifically precise evaluation of mine water quality should be considered. As a result of these initial studies, we can report that direct measurement of bioluminescence resulting from ATP, using a luminometer, is a fast and reliable technique for evaluating the characteristics of mine waters in real-time. There is a strong and positive 
correlation between bioluminescence measured in mine waters in the range 132-239 RLU and water chroma (Figure 2). Mine waters from surface drainage contained significantly less ATP than mine waters from deep drainage (Table 2). It means that in clean mine waters from deep drainage, conditions for the development of microorganisms were better than in the case of surface drainage.

Detection of ATP could be used in the future to estimate the mixing ratio of subsurface drainage in mixed discharges of the two types of lignite mine waters, and to identify mixing zone length and the point of complete mixing in rivers affected by sewage discharge. According to earlier studies [5], knowledge of this length is crucial for estimating the environmental impact of this sector of industry on aquatic ecosystems. Our results can be used where there is a need to shorten the length of the mixing path, and thus, to minimize side effects of mining and energy generation.

Author Contributions: Conceptualization, R.S. and D.C.-S.; methodology, R.S. and D.C.-S.; investigation, P.B.; resources, Ł.K.K.; writing—original draft preparation, D.C.-S. All authors have read and agreed to the published version of the manuscript.

Funding: This research was funded by Polish Ministry of Science and Higher Education, grant number 506.868.06.00/UPP.

Institutional Review Board Statement: Not applicable.

Informed Consent Statement: Not applicable.

Data Availability Statement: The data presented in this study are available on request from the corresponding author.

Conflicts of Interest: The authors declare no conflict of interest.

\section{References}

1. Eurocoal. Coal in Europe. 2019. Available online: https://euracoal.eu/info/euracoal-eu-statistics/ (accessed on 30 October 2020).

2. Wachowiak, G.; Galiniak, G.; Jończyk, W.; Martyniuk, R. Evaluation of outflow changes in the Widawka river basin in the hydrological year 2010 under the impact of a mining and energetics project in the Bełchatów region. Górnictwo $i$ Geoinżynieria 2011, 35, 381-395. (In Polish)

3. Pepliński, B.; Czubak, W. The influence of opencast lignite mining dehydration on plant production-a methodological study. Energies 2021, 14, 1917. [CrossRef]

4. Domska, D.; Raczkowski, M. Effect of strip mine activity on changes of some physicochemical properties of soil. Acta Agroph. 2008, 12, 73-77.

5. Staniszewski, R. Heavy metals in waters and sediments of rivers affected by brown coal mine waters. Pol. J. Environ. Stud. 2014, 23, 2217-2222. [CrossRef]

6. Hildmann, E.; Wonsche, M. Lignite mining and its after-effects on the Central German landscape. Water Air Soil Pollut. 1996, 91, 79-87. [CrossRef]

7. Kavouridis, K. Lignite industry in Greece within a world context: Mining, energy supply and environment. Energy Policy 2008, 36, 1257-1272. [CrossRef]

8. Hancock, S.; Wolkersdorfer, C. Renewed demands for mine water management. Mine Water Environ. 2012, 31, 147-158. [CrossRef]

9. Luo, H.; Zhou, W.; Jiskani, I.M.; Wang, Z. Analyzing characteristics of particulate matter pollution in open-pit coal mines: Implications for Green Mining. Energies 2021, 14, 2680. [CrossRef]

10. Friese, K.; Hupfer, M.; Schultze, M. Chemical characteristics of water and sediment in acid mining lakes of the lusatian lignite district. In Acidic Mining Lakes; Environmental Science; Geller, W., Klapper, H., Salomons, W., Eds.; Springer: Berlin/Heidelberg, Germany, 1998. [CrossRef]

11. Hammes, F.; Goldschmidt, F.; Vital, M.; Wang, Y.; Egli, T. Measurement and interpretation of microbial adenosine tri-phosphate (ATP) in aquatic environments. Water Res. 2010, 44, 3915-3923. [CrossRef]

12. Yang, N.C.; Ho, W.M.; Chen, Y.H.; Hu, M.L. A convenient one-step extraction of cellular ATP using boiling water for the luciferin-luciferase assay of ATP. Biochem. Anal. 2002, 306, 323-327. [CrossRef]

13. Cais-Sokolińska, D.; Pikul, J.; Wójtowski, J. Use of bioluminescence in the assessment of the degree of cleanliness of milk tanks in goat milk processing plants. Arch. Lebensmittelhyg. 2010, 61, 75-79. [CrossRef]

14. Cais-Sokolińska, D.; Wójtowski, J.; Pikul, J.; Dobrzańska, A. An attempt at the specification of common cleanliness limits for abiotic surfaces in dairy processing plants based on ATP bioluminescence. Arch. Lebensmittelhyg. 2016, 67, 12-16. [CrossRef] 
15. Montanez, G.; Passman, F.; Machtiger, N.; Montemayor, R.; Whalen, P. Bioluminescence testing for rapid detection of microbial contamination in aqueous polymer emulsions. Int. Biodeterior. Biodegradation 2016, 114, 216-221. [CrossRef]

16. Deininger, R.A.; Lee, J. Rapid determination of bacteria in drinking water using an ATP assay. Field Anal. Chem. Technol. 2001, 5, 185-189. [CrossRef]

17. European Commission. Technical Background Document on Identification of Mixing Zones, EU Common Implementation Strategy Document "Guidelines for the Identification of Mixing Zones under the EQS Directive (2008/105/EC); European Commission: Brussels, Belgium, 2010; p. 34.

18. Kaszyński, P.; Kamiński, J. Coal demand and environmental regulations: A case study of the Polish power sector. Energies 2020, 13, 1521. [CrossRef]

19. HACH Company. Hach Methods Approved/Accepted by the USEPA, Colorado, USA. 1999, p. 12. Available online: https: //www.hach.com/cms/documents/pdf/EPA (accessed on 30 October 2020).

20. HACH. Water Analysis Guide. DOC316.53.01336. 2013. Available online: https://www.hach.com/WAH (accessed on 30 October 2020).

21. Staniszewski, R.; Szoszkiewicz, K.; Zbierska, J.; Leśny, J.; Jusik, S.; Clarke, R.T. Assessment of sources of uncertainty in macrophyte surveys and the consequences for river classification. Hydrobiologia 2006, 566, 235-246. [CrossRef]

22. Lewicki, P.P. Water as the determinant of food engineering properties. A review. J. Food Eng. 2004, 61, 483-495. [CrossRef]

23. ISO. Milk-Determination of Freezing Point-Thermistor Cryoscope Method Reference Method; ISO 5764, IDF bulletin $\mathrm{N}^{\circ} 42$; International Dairy Federation: Brussels, Belgium, 2009.

24. Regulation of the Minister of Maritime Economy and Inland Navigation of July 12, 2019 on substances particularly harmful to the aquatic environment and the conditions that must be met when discharging sewage into waters or soil, as well as draining rainwater or snowmelt to water or water devices. J. Laws 2019, 1311, 1-48. (In Polish)

25. Ming, F.; Chen, L.; Li, D.; Du, C. Investigation into Freezing Point Depression in Soil Caused by NaCl Solution. Water 2020, 12, 2232. [CrossRef]

26. Martuzzi, F.; Summer, A.; Formaggioni, P.; Mariani, P. Milk of Italian Saddle and Haflinger nursing mares: Physico-chemical characteristics, nitrogen composition and mineral elements at the end of lactation. Ital. J. Anim. Sci. 2004, 3, 293-299. [CrossRef]

27. Navratilova, P.; Janstova, B.; Glossova, P.; Vorlova, L. Freezing point of heat-treated drinking milk in the Czech Republic. Czech J. Food Sci. 2006, 24, 156-163. [CrossRef]

28. Staniszewski, R.; Jusik, S. Impact of mine waters discharge from open-pit lignite mine on river water quality. Rocznik Ochrona Środowiska (Annual Set Environ. Protect.) 2013, 15, 2652-2665.

29. Watanabe, A.; Tamaki, N.; Yokota, K.; Matsuyama, M.; Kokeguchi, S. Monitoring of bacterial contamination of dental unit water lines using adenosine triphosphate bioluminescence. J. Infect. Hosp. 2016, 94, 393-396. [CrossRef]

30. Magic-Knezev, A.; Van Der Kooij, D. Optimisation and significance of ATP analysis for measuring active biomass in granular activated carbon filters used in water treatment. Water Res. 2004, 38, 3971-3979. [CrossRef]

31. Vang, Ó.K.; Corfitzen, C.B.; Smith, C.; Albrechtsen, H.J. Evaluation of ATP measurements to detect microbial ingress by wastewater and surface water in drinking water. Water Res. 2014, 64, 309-320. [CrossRef]

32. Li, G.Q.; Yu, T.; Wu, Q.Y.; Lu, Y.; Hu, H.Y. Development of an ATP luminescence-based method for assimilable organic carbon determination in reclaimed water. Water Res. 2017, 123, 345-352. [CrossRef]

33. Okibe, N.; Johnson, D.B. A rapid ATP-based method for determining active microbial populations in mineral leach liquors. Hydrometallurg 2011, 108, 195-198. [CrossRef]

34. Greenstein, K.E.; Wert, E.C. Using rapid quantification of adenosine triphosphate (ATP) as an indicator for early detection and treatment of cyanobacterial blooms. Water Res. 2019, 154, 171-179. [CrossRef]

35. Zamyadi, A.; Choo, F.; Newcombe, G.; Stuetz, R.; Henderson, R.K. A review of monitoring technologies for real-time management of cyanobacteria: Recent advances and future direction. Trac. Trends Anal. Chem. 2016, 85, 83-96. [CrossRef]

36. Korak, J.A.; Wert, E.C.; Rosario-Ortiz, F.L. Evaluating fluorescence spectroscopy as a tool to characterize cyanobacteria intracellular organic matter upon simulated release and oxidation in natural water. Water Res. 2015, 68, 432-443. [CrossRef] 